\title{
Connectivity in the Western Balkans Region - Difficulties, Challenges and Alternatives
}

\author{
Stanislav Stanev ${ }^{*}$ \\ ${ }^{1}$ University of Plovdiv Paisii Hilendarski, Department of Management and Quantitative Methods in \\ Economics, 24 Tsar Asen Str., Plovdiv 4000, Bulgaria
}

\begin{abstract}
The countries of the Western Balkans have declared their foreign policy priority membership not only in NATO but also in the European Union. Achieving these goals is associated with overcoming many challenges of different nature. Although not directly related to the country's de facto membership of the EU, its infrastructure and the level of its connection with its neighbors raises many of the issues important to society and forms many of its immediate priorities. Difficulties in interconnectedness between countries can have both a political and a geographical basis. In this regard, a serious challenge for the Republic of Northern Macedonia is the level of connection with its eastern and western neighbors. Almost 30 years after the declaration of independence, the infrastructure continues to follow the realities set and realized by Socialist Yugoslavia. This in turn poses many difficulties for the economic development of the whole region. A significant part of the reasons for the lack of progress are also due to purely geographical reasons, but alternative solutions can be sought to overcome the backlog in connectivity.
\end{abstract}

\section{Introduction}

When commenting on the region of the Western Balkans, those countries that are not part of the European Union are usually considered. These include, in particular, the Republic of North Macedonia, the Republic of Albania, Kosovo, Montenegro, Bosnia and Herzegovina. All these countries have declared accession to the European Union as their main foreign policy priority. And three of these countries are already members of NATO - the Republic of Northern Macedonia, Albania and Montenegro. The routes of two of the main panEuropean corridors - eight and ten - pass through the Western Balkans. With its central location in this region and the fact that both corridors pass through its territory, the Republic of Northern Macedonia occupies an important place. The latter should be part of the state's priorities in the development of its infrastructure.

\footnotetext{
*Corresponding author: st.stanev@advokat.bz
} 


\subsection{The country}

The independent way the Republic of Northern Macedonia as a country began in 1991 as part of the process of disintegration of the Socialist Federal Republic of Yugoslavia. Following a referendum held in September of the same year, Skopje declared its independence on November 17, 1991. [1] The new state received its first official recognition from the Republic of Bulgaria on January 15, 1992, and a little later, after intense diplomatic activity by the latter, the Russian Federation also recognizes independence. [2] This marks the beginning of the independent existence of the state, which in the following years began to develop its relations with other countries. In reality, the Republic of Northern Macedonia and Montenegro are the only former Yugoslav republics that have managed to gain independence without having to wage war. Unlike Montenegro, which, however, fought as part of the rest of Yugoslavia and now gained independence, Macedonia is not involved in an armed conflict at all. A kind of exception is the tension in 2001, when there were ethnic clashes near the village of Arachinovo, near Skopje and close to a highway. It was the fact that this threatened a serious transport corridor that led the international community to intervene to find a permit. [3] The latter shows the importance of the major transport corridors not only for connectivity but also for the overall security environment.

\subsection{Transport infrastructure}

The Republic of Northern Macedonia is an "internal state", it has no access to the sea or navigable rivers. Its connections with neighboring countries are air, road and rail. [4] Nevertheless, the country is located at an important transport crossroads, with eight and ten Pan-European Corridors running through its territory.

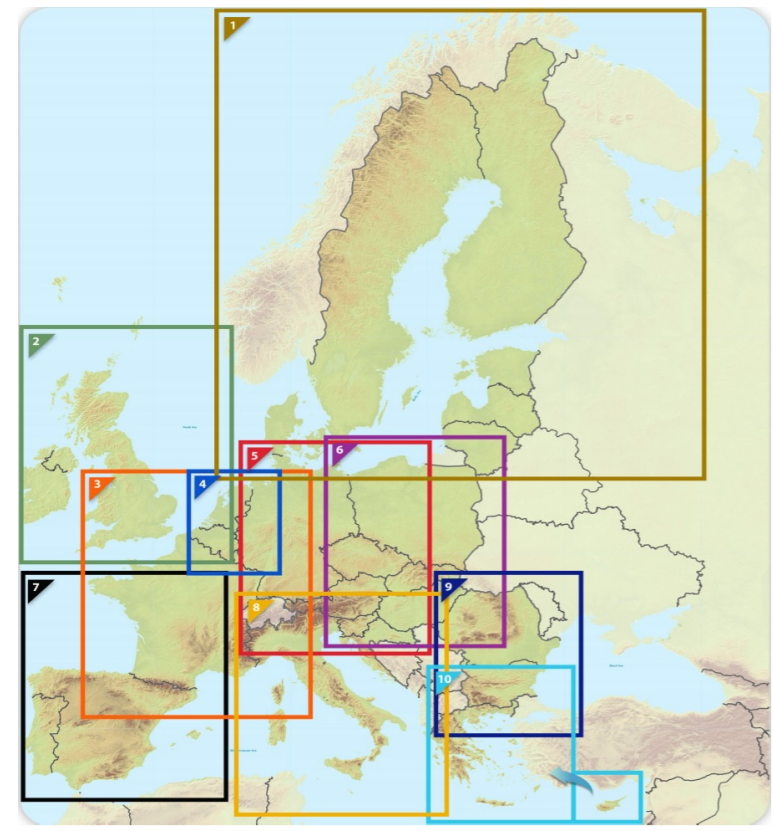

Fig. 1. Pan-European corridors and the countries in Europe

Source: European Commission, https://ec.europa.eu/transport/infrastructure/tentec/tentecportal/site/en/maps.html 
This predetermines its important position in terms of transport connections and the importance of the latter. However, the infrastructure situation in the Republic of Northern Macedonia has not developed seriously enough at this stage. To a large extent, the transport network is a legacy of socialist Yugoslavia and can be said to reflect Belgrade's infrastructural priorities. As part of this, serious efforts have been made in the transport corridors connecting the country with Western Europe on the one hand and with the ports in its southern neighbor and in particular in Thessaloniki. Macedonia (then a union republic) is on the route of these transport corridors, which predetermines the efforts made by Yugoslavia in the construction of transit transport corridors. In addition, the level of connection of this part of Socialist Yugoslavia, which is now the independent state of the Republic of Northern Macedonia, with Bulgaria and Albania indicates the extent to which the two countries' ties with the then federal republic were a priority for the federal state.

The analysis of the transport corridors and connections of the Republic of Northern Macedonia shows that the country has a relatively well-developed north-south transport direction, at the expense of the significantly less developed east-west. In particular, this is expressed in the following:

The country has its own highway links with Serbia and Greece [6]. The M-1 highway, which in Macedonia starts from the Tabanovce border checkpoint on the border with Serbia and continues to the Bogoroditsa border checkpoint - on the border with Greece. The total length of this highway is 173 kilometers, which are practically completed. The highway is part of the European road E75 and the Pan-European Corridor № 10. The highway was built within the SFRY in the period 1959-1964 as part of the road "Brotherhood and Unity". In 2008, as part of the then dynamic process of "antiquization", the highway was named "Alexander the Great". In 2018, as part of Skopje's intensive efforts to improve its relations with its southern neighbor with a view to joining NATO and the EU, the highway was renamed "Friendship" [5].

\subsection{Railway transport}

The issue of railway corridors is similar as above. The Republic of Northern Macedonia has its ties with Serbia and Kosovo (as part of the Yugoslav heritage) and with Greece. [7] The issue of railways is particularly important when commenting on connectivity in the context of not so much passenger transport as the transport of goods.

In the Republic of Northern Macedonia, in a westerly direction, it reaches the town of Kichevo by rail. It was built during the First World War for military purposes but was also used for civilian purposes. [8] Immediately after the end of the war, a close line was established with the towns of Struga and Ohrid, located on Lake Ohrid. Subsequently, this line (from Kichevo to Ohrid and Struga) was dismantled. To date, no real action has been taken to build another railway line on the site of the dismantled one.

The western neighbor, the Republic of Albania, also does not have a well-developed railway network. In practice, it has only one international connection - with Montenegro, from where, however, only cargo is transported. Nevertheless, the state has made efforts to build a line to its eastern border. On the Albanian side, the railway line reaches the town of Pogradec, which is located on Lake Ohrid [8]. The distance from the village of Lin (the nearest railway-connected settlement in Albania to the eastern border) to the Kafasan border checkpoint is less than ten kilometers. I.e., Albania needs to make very little effort to connect with its eastern neighbor. Things are different on the other side of the border. As it became clear, after the dismantling of the narrow-gauge railway reaching Struga and Ohrid, the closest station to the border with Albania is Kichevo. The distance from there to the checkpoint is more than 70 kilometers. This, as well as the fact that in the absence of an 
international connection, the railway line from Elbasan to Pogradec is not sufficiently busy, predetermines the lack of profitability, and hence insufficient investment in maintenance and improvement of the line by Albania. Therefore, since 2012, the movement of trains has been suspended. Macedonia's lack of serious intentions has prompted the Albanian government to discuss alternatives to international rail connectivity. In 2018, the project for a railway line from the town of Pogradec, through Korca to the town of Lerin in Greece was announced. [9] At this stage, the actual construction of this line has not started. However, the fact that the issue is being discussed at the international level shows Tirana's serious intention to connect to the east. And given that the Republic of Northern Macedonia has not demonstrated serious enough intentions, it is normal not only to discuss but also to start a project to connect the coastal (Lake Ohrid) town of Pogradec with the Greek railway network. In the implementation of this route, there will be a kind of bypass of Macedonia in the direction of Corridor Ko 8. Which in turn is an unfavorable prospect for the country, which due to its geographical location should be built as a transport hub. Which is important for its economy given the lack of access to the sea and navigable rivers through which it can connect with other countries in other ways.

The railway connection of the Republic of Northern Macedonia with its eastern neighbor - Bulgaria, is no different from that with the western one. The issue of the degeneration of the railway line in this direction has been relevant for more than 100 years. The military conflicts in the first quarter of the twentieth century and the nature of international relations after them became the reason for not starting this project. In 1941, after the territory of today's Republic of Northern Macedonia was handed over to the Kingdom of Bulgaria, the issue of building a railway line connecting Sofia and Skopje became relevant again. To date, on the Bulgarian side, the route is ready almost to the border. Given the elapsed time and the fact that it is not used, it is necessary to make modernization. [10] On the Macedonian side, the situation is quite different. The route there should start from the town of Kumanovo, pass through the towns of Kratovo and Kriva Palanka and reach the border with Bulgaria. This section is the most difficult to build because of the mountainous terrain, which requires the construction of many bridges, tunnels and other facilities. All this significantly increases the cost of the route and is one of the frequently cited excuses by Skopje for the lack of a railway connection between the two countries.

The above explains the commented lack of adequate communication of the Republic of Northern Macedonia in the east-west direction. The latter is the reason for the poor communication of the state with its neighbors in every respect, including economically. And it was also one of the reasons for the severe blow suffered by the economy of the Republic of (then) Macedonia in 1995. As part of the name dispute, Greece imposed an economic blockade, which included the inability of its northwestern neighbor to use the port of Thessaloniki. In the other direction with a well-developed infrastructure - the north, the situation was also complicated by the armed conflicts that accompanied the break-up of Yugoslavia. [1] Then Macedonia's eastern and western neighbors, Bulgaria and Albania, provided the landlocked country with the opportunity to use the ports of Bourgas and Durres. Although this was a relief for Skopje, the effect was not the desired level. The reason for this is precisely the poor connection of the country with Bulgaria and Albania, inherited from Yugoslavia, which continues to be relevant today. 


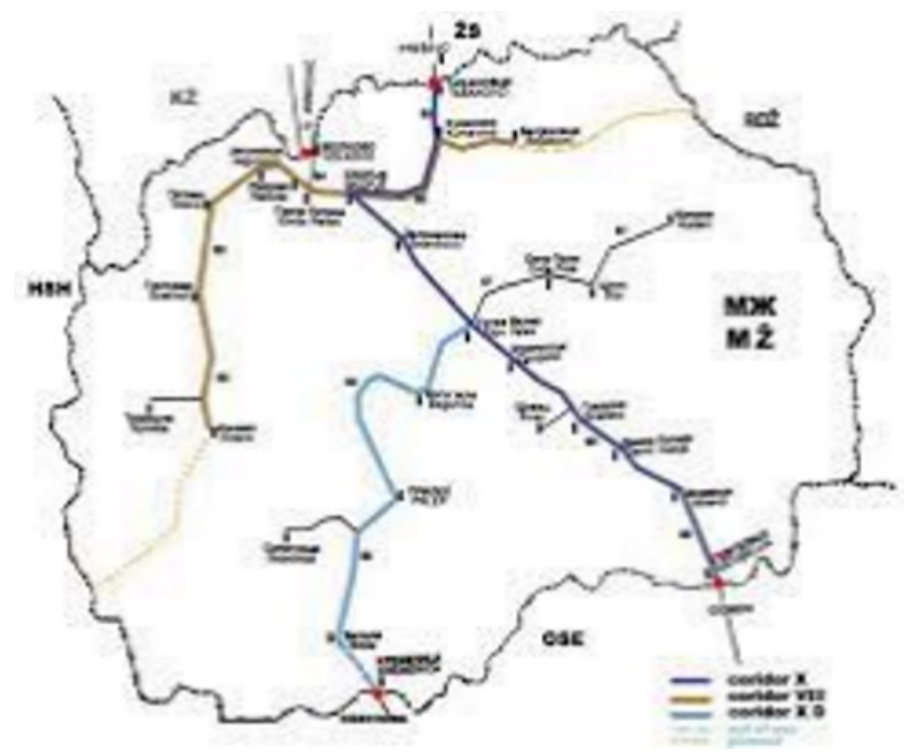

Fig. 2. Network of the Macedonians railways

Source: report for the former Yugoslav republic of Macedonia, Sector Operational Programme for Transport 2014-2020, available at: https://ec.europa.eu/neighbourhoodenlargement/sites/near/files/pdf/the former_yugoslav_republic_of_macedonia/ipa/2015/20120212sop-transport-after-ipa-comittee.pdf,

The three countries Albania-Northern Macedonia-Bulgaria are along the route of the Pan-European Corridor №8, which connects the port of Bari in Italy with those of Varna and Bourgas - in Bulgaria. [11] The construction of the corridor is of particular importance both for the countries on whose territory its route is located and for the entire European Union. It is of particular importance to the Republic of Northern Macedonia. As noted above, the latter's lack of efforts to build rail links with its eastern and western neighbors calls into question the effective implementation of this corridor. This not only complicates communications and trade relations with these other countries, but also leads to discussions on other transport routes, which will be a kind of bypass of that of Corridor №8 and will largely eliminate its effective implementation. This, in turn, will have a negative impact on the Republic of Northern Macedonia in its ability to dynamize communications, including its economic ties with Bulgaria and Albania.

As described above, the main obstacle pointed out by Skopje to the railway connection between Bulgaria and Macedonia is the peculiarities of the relief between Kriva Palanka and the border with Bulgaria. However, this is far from the only possible route that can connect the two countries. The border between Bulgaria and Macedonia is 165 kilometers long. [4] Indeed, a significant part of it passes through mountainous areas, which is a difficulty for the implementation of infrastructure projects along the entire border. However, there are also areas where the situation is different.

The Bulgarian town of Petrich, located in the southwestern part of the country, is connected by a railway line, which is part of the network of the Republic of Bulgaria. From Petrich to the nearest town in the Republic of Northern Macedonia - Strumica the distance is about fifty kilometers. Unlike the route in the direction Kriva Palanka - Kyustendil, here the terrain is flat and does not pose serious challenges, which require the construction of complex and expensive facilities, such as tunnels and bridges. The Petrich - Strumica route was assessed by the General Staff of the Bulgarian Army during the First World War. [12] 
In order to supply the Bulgarian units on the front lines, the construction of a railway line from Petrich to Strumica was designed and started. The section is paved and a significant part of it was built in less than a year. It is a narrow-gauge railway. The end of the war and the international commitments made caused the line to be dismantled and in the following decades the connection between Petrich and Strumica to remain only a road. Given the fact that the construction of the line was started and largely realized more than 100 years ago and with the technologies available at that time show a good opportunity, which is relevant to this day and allows the implementation of this project to be discussed today point of view.

The town of Strumica, to which the tracing was made, is one of the relatively large towns in the Republic of Northern Macedonia. It is located $150 \mathrm{~km}$ from the capital Skopje. In addition to the Zlatarevo border checkpoint (about $30 \mathrm{~km}$ ), there are also two border checkpoints with Greece: Star Doyran (at Doyran Lake) - a small checkpoint with local significance $45 \mathrm{~km}$ and at about the same distance from the Bogoroditsa border checkpoint with Greece, which is located on the M-1 highway. The nearest airport is $135 \mathrm{~km}$ from Skopje, while Smokvica and the railway line are about $30 \mathrm{~km}$ away. Approximately the same is the distance to the M-1 highway. This shows that the greatest importance for the development of the municipality of Strumica and the entire southeastern region of the country is the proximity to the Republic of Bulgaria.

As mentioned, the nearest railway station to Strumica is at a distance of about 30 kilometers. It should be noted that west of the city, in the direction of this railway line, the terrain is hilly in places, which is probably one of the reasons for the lack of a railway connection. Strumica is located $67 \mathrm{~km}$ from the town of Shtip - the same is in the direction of the railway line Veles-Kochani, which is connected to the rest of the railway infrastructure of the country. The road from Strumica to Shtip is relatively flat. Therefore, there is a wide road built there, which is currently being expanded and modernized. The peculiarities of the relief raise the issue of the design of a railway line between the two settlements. Here it is necessary to note that in this direction there is another relatively large by the standards of Macedonia city - Radovis. Which means that the presence of a railway line will have a favorable impact on its development.

The design and construction of a route connecting Strumica on the one hand with Petrich and the railway network of Bulgaria and on the other with Shtip will have a serious positive impact not only on these cities, but also in practice for the entire southeastern region of Northern Macedonia. This is a serious prerequisite for the revival of economic and other ties between the two countries. The total length of the route, which must be built to achieve the commented connectivity, is about 120 kilometers. Although the length of this route is greater than the line from Kumanovo through Kriva Palanka to the border with Bulgaria, here the investment will be much smaller due to the commented favorable relief features.

In the analysis of the possibilities of connection of the South-Eastern region of Macedonia with the Republic of Bulgaria it is necessary to consider the other possibilities as well. There is a railway line between the towns of Veles and Kochani. In the direction of the same is located and Shtip. From Kochani, where the line ends, to the border with Bulgaria, the distance is about $60 \mathrm{~km}$, and to Blagoevgrad, where the nearest railway line is located - about $90 \mathrm{~km}$. Compared to the direction described above, this is about 30 kilometers less. However, the route is significantly more complicated - with mountainous terrain, which would make construction very difficult. In addition, the realization of such a route (from Blagoevgrad through Kochani to Shtip) would leave Strumica isolated, which is an additional argument in favor of the idea of realizing a railway line from Petrich through Strumica to Shtip. 
Of course, the discussed possible railway route from Strumica to Bulgaria and from Strumica to Shtip should not be considered as an alternative to the line Skopje - Sofia through Kriva Palanka and Kyustendil. The latter is the shortest route between the two capitals, which requires both countries to make efforts. However, since the implementation of this route is experiencing difficulties of different nature, there is no obstacle to make efforts to build a second relationship, which on the one hand will not cost such serious efforts, on the other hand will help to dynamize relations between the two countries. and specifically, in the Petrich-Strumica border regions.

\section{Conclusion}

Without the development of infrastructure and the improvement of connectivity, especially with its eastern and western neighbors, the membership of the Republic of Northern Macedonia in the European Union will hardly be able to meet all the expectations of its citizens. Improving the possibility of communication is in the interest not only of the state, but also of the entire European Union. And given that the situation with Corridor № 10 is relatively good, it is necessary to make efforts for the other direction. Although Skopje declares that it is a priority for the state, in reality there is a continuity in the policies of the various governments, which in two directions. It is officially stated that the construction of Corridor №8 is a priority for the state. In reality, not enough serious action is taken to form the belief that this is indeed the case. The obstacles of a financial nature declared by Skopje could be overcome with various instruments involving the EU, but no serious efforts are being made in this area either. The above necessitates discussing options for alternative transport routes, which will be important both for regions of the country and in general and will be a good opportunity until the completion of Corridor №8 and beyond.

The analysis also shows that the lack of serious efforts by the Republic of Northern Macedonia to develop its international transport connectivity in the east-west direction (in the direction of Corridor 8) will result in delayed economic development of the country.

\section{References}

1. B. Banchev. Bulgaria and the Yugoslav crisis (1989-1995), (University Publ. House St. Kliment Ohridski, 2009)

2. Zh. Zhelev, In big politics, (Publ. House Trud,1998)

3. Vistinata za Arachinovo, documentary about the conflict in Arachinovo in 2001, https://www.youtube.com/watch?v=TEnGfCFMneA

4. G. Georgiev, Former Yugoslav Republic of Macedonia. Tourist geography, (Publ. House Geya Libris, 9-19, 2016)

5. Information portal B92, changing name of the highaway, https://www.b92.net/eng/news/region.php?yyyy=2018\&mm=02\&dd=21\&nav_id=103 546

6. Roads in the Republic of North Macedonia, http://www.roads.org.mk/255/roadnetwork

7. The official web page of the railways of Republic of North Macedonia, https://mzt.mk/?lang=mk

8. The official web page of the railways of Albania, https://hsh.com.al/ 
9. M. Zasiadko, Albania and Greece consider interstate rail connection, [Online], https://www.railtech.com/infrastructure/2018/11/27/albania-and-greece-considerinterstate-rail-connection/?gdpr=accept

10. L. Gramitska, Corridor №8 project of two centuries between Bulgaria and Macedonia, [Online], https://www.mediapool.bg/koridor-8-proekt-na-dva-veka-mezhdu-bulgaria-imakedoniya-news322884.html

11. The core transport network, South-East Europe Transport Observatory, [Online], https://ec.europa.eu/neighbourhood-enlargement/sites/near/files/pdf/projects-infocus/donor-coordination/2-3_april_2009/working_group_transport_seeto_en.pdf

12. A. Dzhonev, Makedoniya v zhelezopatnata politika na Balgariia (1878-1918), (Regionalen istoricheski muzey „Akad. Yordan Ivanov” Kyustendil, 2008)

1. Angel Dzhonev, Macedonia in the railway politic of Bulgaria(1878-1918), regional historical museum Kyustendil (2008) 